\title{
Augusto Monterroso Impersonates and Translates
}

\author{
Elena MADRIGAL*
}

Augusto Monterroso's witty short-shorts have been praised and extensively appreciated and studied. Despite their deep connections with his authorial poetics, his translations, his translation experiences, and his ideas on translation have not received the same attention. So, after a detective-like search on the Eduardo Torres character/person, this paper speculates on the motivations that led Monterroso to create a polymath character who not only translated Fisches Nachtgesang (A fish's nocturne) by Christian Morgenstern and published $A$ Modest Proposal by Jonathan Swift more than once, but also reflected on translation issues as well. While exploring some of Monterroso's own thoughts on translation, the paper offers some explanations on why Monterroso decided to translate, under his name, "An Autobiographical Sketch" by Charles Lamb and three biographies by John Aubrey. The final aim of this paper is to show how Monterroso found the exact amounts of irony, disenchantment, and hope to blur the boundaries among 'real' life translating, creating a fictional character, and writing a novel on him. In that way, his unified artistic system can also be examined under the light of his aesthetic affinities with his chosen authors, his approaches to translation, and the thematic and compositional coincidences between his source texts, his essays, and his fiction.

Keywords: character/author construction; irony; authorial/translational poetics; Jonathan Swift; John Aubrey

From the very first time I tried to translate something, I knew that if there is someone we must be patient and empathic with, that someone is the translator, a melancholic and dubitative being, as a rule.

-Augusto Monterroso, "On the translation of some titles"

\section{Caught in the (First) Trap}

I came across Eduardo Torres's translation of Jonathan Swift's A Modest Proposal ([1729] 1996) into Spanish while in search for studying materials for a Translation Criticism Seminar I was to teach years ago. Torres's translation was published in the prestigious literary journal Revista de Bellas Artes in 1965. It was introduced by Augusto Monterroso (Tegucigalpa, Honduras, 1921-Mexico City, 2003), a well-respected and famous writer in Mexico and Latin America, who, by the time of my search, had become a canonical prose writer

\footnotetext{
* Professor, researcher, and Master in Translation coordinator at El Colegio de México. E-mail: madrigal@colmex.mx; ORCID ID: https:/orcid.org/0000-0002-8212-0334. (Received 20 February 2020; accepted 21 May 2020)
} 
in the Hispanic world. ${ }^{1}$ The translation was profusely illustrated by the worldwide iconic Mexican artist José Luis Cuevas. Both paratexts led me to think I had the most suitable translation before me since one of the goals of my course was for my students to avoid making negative comments on translations, but to make inferences on translation projects instead. So, after leaving Monterroso's introduction for a more suitable moment, I proceeded to confront Swift's source text with Torres's translation with the aim of illustrating Antoine Berman's deformations ([1995] 2009) or Lance Hewson's (2011) micro, meso, and macrotextual shifts, perhaps.

Having agreed with Robert Phiddian's idea that the voice of the Proponent is a central key to Swift's text, I found that Torres's translation rendered both the voice of the Proposer and Swift's satirical aim quite well. As it is shown in table 1, it is noticeable that Torres opted for one verb in present ('es') and a steady use of future tense to give the impression that the speaker is able to predict consequences on a scientific basis. The ethos is reinforced by 'toda vez que,' a conjunctive phrase which adds a formal tone:

Table 1. The voice of the Proponent

\begin{tabular}{|c|l|}
\hline Swift ([1729] 1996, 56) & \multicolumn{1}{|c|}{ Torres $(1965,48)$} \\
\hline $\begin{array}{r}\text { Secondly, the poorer tenants will } \\
\text { have something valuable of their own, which } \\
\text { by law may be made liable to distress, and } \\
\text { help to pay their landlord's rent, their corn } \\
\text { and cattle being already seized, and money a } \\
\text { thing unknown. }\end{array}$ & $\begin{array}{l}\text { Les arrendatarios más pobres } \\
\text { poseerán algo propio de valor, que por ley } \\
\text { podrá estar sujeto a embargo, y que los } \\
\text { ayudará a pagar el arriendo a sus señores, } \\
\text { toda vez que su ganado y su trigo han sido } \\
\text { ya confiscados y el dinero es algo que } \\
\text { desconocen. (emphasis added) }\end{array}$ \\
\hline
\end{tabular}

Swift's satire also rests on a legal and economic discourse which emphasizes the legitimacy of the arguments. Torres translates this net of law terms well by using precise terminology, as we can notice in the rendering of 'tenants' into 'arrendatarios,' 'liable to

\footnotetext{
${ }^{1}$ He was awarded the 1952 "SakerTi” National Tale Prize in Guatemala, the 1970 Magda Donato Prize in Mexico, the 1975 Xavier Villaurrutia in Mexico, the 1985 Juchimán de Plata from the Tabasco Juárez University in Mexico, the 1988 Águila Azteca Medal in Mexico, the 1996 "Juan Rulfo" Award in Mexico, the 1997 "Miguel Ángel Asturias" National Literary Award in Guatemala, and the 2000 Prince of Asturias Award in Literature in Spain (Ruffinelli 2001, 14; "Augusto Monterroso: Prince of Asturias Award for Literature," Fundación Princesa de Asturias, accessed May 15, 2020, http://www.fpa.es/en/princess-of-asturias-awards/laureates/2000-augustomonterroso.html?texto $=$ trayectoria\&especifica $=0)$.
} 
distress' into 'sujeto a embargo,' 'landlord' into 'señores,' and 'seized' into 'confiscados,' as it is shown in table 2.

Table 2. Legal and economic jargon

\begin{tabular}{|c|l|}
\hline Swift ([1729] 1996, 56) & \multicolumn{1}{|c|}{ Torres $(1965,48)$} \\
\hline $\begin{array}{r}\text { Secondly, the poorer tenants will } \\
\text { have something valuable of their own, which } \\
\text { by law may be made liable to distress, and } \\
\text { help to pay their landlord's rent, their corn } \\
\begin{array}{l}\text { and cattle being already seized, and money a } \\
\text { thing unknown. }\end{array}\end{array}$ & $\begin{array}{l}\text { Los arrendatarios más pobres } \\
\text { poseerán algo propio de valor, que por ley } \\
\text { podrá estar sujeto a embargo, y que los } \\
\text { ayudará a pagar el arriendo a sus señores, } \\
\text { toda vez que su ganado y su trigo han sido } \\
\text { ya confiscados y el dinero es algo que } \\
\text { desconocen. (emphasis added) }\end{array}$ \\
\hline
\end{tabular}

Despite such success, and that Swift's piece "is grotesque without being carnivalesque"-following Phiddian (1996, 603)—some of Torres's translating decisions seemed inconsistent, exaggerated, and contradictory at times. One group had to do with domestication and foreignization, whereas a second set of decisions led to a confusion between feudal and capitalist economic systems, as summarized in tables 3 and 4, respectively. The first issue arose when the word "chamacos" (Torres 1965, 42) for "children" (Swift [1729] 1996, 52) appeared in the second paragraph, since 'chamacos' belongs to an oral, colloquial, Mexican register ${ }^{2}$ which conflicts with Torres's preservation of the geographical setting of the proposal in the phrase "condado de Cavan" (45). Torres's domestication was also contradicted in his translation of cooking methods and money systems. For example, he rendered "fricassee" (54) — of French origin — as the undoubtedly Mexican "mole verde"3 (53) and "ragout" (53) _ also of French origin - as "a la vinagreta" (45), a more familiar vinegar-based cooking procedure to Mexican tastes. Such decisions agreed with translation of "groat" (55) as "peso" (47) and "penny" (59) as "centavo" (51). However, 'peso' and 'centavo' conflicted with his keeping the direct terms for other coins, such as "chelines" $(46,48)$ for "shillings" $(54,56,57)$ or "libras esterlinas" (51) for " $l$. sterling" (58).

\footnotetext{
${ }^{2}$ Both the Diccionario de la Lengua Española and the Diccionario del Español Usual de México agree on this point.

${ }^{3}$ Also called "pipián," a thick sauce made with pumpkin toasted and powdered seeds, ripen Poblano peppers, other chilis (such as green chili), and sesame seeds (Diccionario del Español de México, s.v. "pipián," accessed May 15, 2020, https://dem.colmex.mx/Ver/pipián).
} 
Table 3. Torres's domestication and foreignization conflicts

\begin{tabular}{|l|l|}
\hline Swift $([1729] 1996)$ & Torres (1965) \\
\hline children & chamacos \\
fricassee & mole verde \\
ragout & a la vinagreta \\
groat & peso \\
county of Cavan & condado de Cavan \\
penny & centavo \\
shillings & chelines \\
l. sterling & libras esterlinas \\
\hline
\end{tabular}

As to the second type of decisions, some terms fit the agricultural structure alluded by Swift, and some others contradict it because they belong to the capitalist system terminology. As table 4 illustrates, while "cottagers" (Swift [1729] 1996, 54) is translated as "rancherías" (Torres 1965, 45) and "labourers" (54) as "braceros" (45), "the nation's stock" (56) is turned into "producto nacional bruto" (48; national gross domestic product), "of no expense" (58) becomes "fuga de divisas" (51; flight of capital), and "the goods being entirely of our own growth and manufacture" (56) becomes "la mercancía se obtendría de nuestro desarrollo interno y de nuestra propia industria" (48; the goods being of our internal growth and of our own industry).

Table 4. Torres's conflicting terminology related to economic orders

\begin{tabular}{|l|l|}
\hline \multicolumn{1}{|c|}{ Swift ([1729] 1996) } & \multicolumn{1}{|c|}{ Torres (1965) } \\
\hline cottagers & $\begin{array}{l}\text { rancherías } \\
\text { braceros }\end{array}$ \\
\hline $\begin{array}{l}\text { labourers } \\
\text { of no expense } \\
\text { the goods being entirely of our own growth stock } \\
\text { and manufacture }\end{array}$ & $\begin{array}{l}\text { producto nacional bruto } \\
\text { fuga de divisas } \\
\text { la mercancía se obtendría de nuestro } \\
\text { desarrollo interno y de nuestra propia } \\
\text { industria }\end{array}$ \\
\hline
\end{tabular}


The task was then to propose an explanation to the intentional 'incongruities' in Torres's translation. Given Berman's emphasis on the necessary coherence between the translator's horizons ([1995] 2009, 63) and his translation decisions for the critic to deduce a translation project (60), the time to look into Monterroso's presentation had come.

\section{A Second Trap: Genre and Character}

\subsection{On Satire as Genre}

Monterroso begins his "Note on the Translation" by introducing himself as the recipient of a grant from an American endowment whose academic authority to do archival research will lead to a reprint of Torres's 1945 translation of Swift's Modest Proposal: “Among Eduardo Torres's papers, which I now classify under the auspice of the St Louis, Missouri, US, Endymion Journal and Publishing House" (Torres 1965, 41; my translation). Monterroso then proceeds to present Torres as a literary critic and writer belonging to the finest classical, modern, and contemporary satirical tradition. He later quotes Torres in his ironic praise of the benefit derived from Swift's Proposal_children in poverty are "but a pitiful memory" (40) a reason that moved Torres to translate the piece. In other words, he decided to offer his version to the public because A Modest Proposal contributed to solve the problems it criticized, becoming a testimony of the good government proceedings and a moral fable for children, thus. The note closes with a sardonic defense of the unmistakable incongruities found in Torres's translation since Monterroso makes them appear conscious and intentional from Torres's part. Monterroso even praises them because they are motivated by Torres's national language pride and scientific terminology rigor. Monterroso explains:

Debo añadir únicamente que el uso de ciertos mexicanismos como "chamacos", "mole verde", "recalentado" y otros . . obedecen al conocido principio de Torres consistente en dar carta de ciudadanía a nuestras mejores expresiones y en incorporar el lenguaje científico a la literatura, "con naturalidad, pero sin desparpajo". (Torres 1965, 41)

(I must only add that the use of certain Mexican terms such as 'chamacos,' 'mole verde,' 'recalentado,' and others . . . are due to Torres's widely known premise which consists in granting citizenship to our utmost expressions and in incorporating scientific terminology in literature 'unaffectedly and without impudence'; my translation)

After enjoying the subtle and obvious sarcasms, I turned to Monterroso's biography to find out details about his research, and I could not help but smile and admire his "Note on the 
Translation," since it is a superb parody of the type of paratexts one finds as preludes to worthy translations. I was surprised to learn that the endowment was fictitious, as much fictional was the Sunday supplement of the equally made-up parochial Heraldo de San Blas newspaper in which the translation "was originally published" (Torres 1965, 41). Eduardo Torres, evidently, was also a fictional character. However, it took Monterroso nineteen years to disclose Torres's invented status when he finally published the novel Lo demás es silencio: La vida y la obra de Eduardo Torres ${ }^{4}$ (The rest is silence: The life and work of Eduardo Torres) in 1978, a period in which he published more than one article ${ }^{5}$ and the translation of $A$ Modest Proposal under the heteronym of Eduardo Torres at least twice, even after the fictional biography. ${ }^{6}$ The fact that Torres reappeared in a verbal duel with William Golding (Monterroso 1996, 288) in $\mathrm{La}$ letra $E$ (The letter E) of 1984 has misled more than one literary or translation critic to take Eduardo Torres "as if he were another intellectual in the Mexican literary circles," as Jorge Ruffinelli (2001, 40; my translation) puts it, a view Francisca Noguerol Jiménez has also expressed $(2000,171)$.

Having discovered the literary device, we may try to figure out why Monterroso chose A Modest Proposal as his source text and an alter ego to sign his work. The "Note on the Translation" provides a hint to the first issue. It was not Torres but Monterroso who was an ironist well acquainted with the satirical Western tradition. It was him who identified himself with those writers who treat their topics with humor and wit. Besides, Monterroso's pieces ridicule social flaws, and they are mostly appreciated for their aesthetic achievements. $\mathrm{He}$ explained this double procedure when asked about "Mr. Taylor," ${ }^{7}$ a story which echoes $A$ Modest Proposal's aim of "offering the most absurd ideas for a supposedly national good with apparent logic and prejudice" (Ruffinelli 2001, 25; my translation). Monterroso explicated:

\footnotetext{
${ }^{4}$ The book was originally published by Joaquín Mortiz in 1978. It was reprinted by Plaza y Janés in 1985 and 1986 in Barcelona and by Rei in 1987 and Era in 1991 in Mexico. It was reprinted by Cátedra with an Introduction by Jorge Ruffinelli in 2001. It has not been translated into English so far, perhaps due to the fact that Monterroso is best known for his short fiction and his aphorisms. The novel was translated into German and into Italian in 1992: Reif sein ist alles und der Rest ist Schweigen: einzig wahrhaftige und autorisierte Version von Leben und Werk des unsterblichen Don Eduardo Torres aus San Blas, trans. Christel Dobernecker (Berlin: Verlag Volk and Welt); Il resto è silenzio: La vita e l'opera di Eduardo Torres, trans. Barbara Bertoni (Palermo: Sellerio Editore). ${ }^{5}$ Noguerol Jiménez gives the first reference: "Una nueva edición del Quijote" "appeared in the Revista de la Universidad de México" $(2000,171)$. The text is in vol. XIII, no. 5, published in January, 1959.

${ }^{6}$ As Ruffinelli explains, the translation was republished in an insert of the Ciencia y Desarrollo journal in 1977 and in the supplement Sábado of the UnomásUno newspaper on April 27, 1985 (2001, 25, n. 20).

7 "Mr. Taylor" was written in La Paz, and it was published in El Siglo, a Chilean newspaper (Centro Virtual Cervantes, accessed May 15, 2020, https://cvc.cervantes.es/actcult/monterroso/cronologia/1921_1956.htm).
} 
"Mr Taylor" fue escrito en Bolivia, en 1954, y está dirigido particularmente contra el imperialismo norteamericano y la United Fruit Company, cuando éstos derrocaron al gobierno revolucionario de Jacobo Arbenz, con el cual yo trabajaba como diplomático. "Mr. Taylor" es mi respuesta a ese hecho y por cierto me creó una cantidad de problemas de orden estético. Yo necesitaba escribir algo contra esos señores, pero algo que no fuera reacción personal mía, ni porque estuviera enojado con ellos porque habían tirado a mi gobierno, lo cual me hubiera parecido una vulgaridad. Claro que estaba enojado, pero el enojo no tenía por qué verse en un cuento. Precisamente en los días de los bombardeos a Guatemala, cuando lo escribí, tuve que plantearme un equilibrio bastante difícil entre la indignación y lo que yo entiendo por literatura. (Ruffinelli 1989, 25)

("Mr Taylor" was written in Bolivia in 1954, and it is targeted at American imperialism and the United Fruit Company for having overthrown the democratic government of Jacobo Árbenz, with whom I worked as a diplomat. "Mr. Taylor" is my response to that historical fact and, by the way, the writing caused me great troubles of an aesthetic order. I needed to say something against those guys, but not as a personal reaction, or not because I was outraged because they had ousted my government. That kind of writing would have seemed vulgar to me. I was outraged, of course, but my anger did not have to surface in a short story. I had to devise a difficult-to-achieve equilibrium between indignation and what I understood by literature precisely during the days of the bombings over Guatemala, when I wrote the piece; my translation)

So, as a translator, Monterroso chose a masterpiece that would combine social concerns, "sanity and restraint of thought, and clearness of expression" (Walker 1915, 116). Even more, he had it published in a format that would round off the homage to periodical essayist ${ }^{8}$ Jonathan Swift. On the one hand, such details reveal his aims as a writer and translator, but on the other hand, they make Torres's translation 'incongruities' more prominent. The "Note on the Translation" offers a key to explain such incompatibilities.

\subsection{On Eduardo Torres and Augusto Monterroso as Characters}

There is a double portrayal in the "Note on the Translation." As we have said, Monterroso pictures himself as a successful scholar who gets published by the best journals of the capital city and who would rescue Torres, a provincial intellectual and writer, for the benefit of the national literary history. Besides, since Torres's translation needs to be justified, Monterroso anticipates counterarguments to the criticisms his 'object of study' would raise. His decision to sign the translation under Eduardo Torres might also have to do with his intention to mock (pseudo-)intellectuals and to underline their deficiencies by using a double-edged tool:

\footnotetext{
${ }^{8}$ As Jane H. Jack explains, one of the main purposes of periodical essayists was to educate readers in the "English sense of respectability," which included topics such as citizenship, religion, and patriotism (1980, 112).
} 
a translation by a fictional intellectual. His heteronym also has to do with a tendency Monterroso's literary critics have observed. For example, Noguerol Jiménez explains that Monterroso's characters are sometimes either losers or parochial, or intellectuals Monterroso makes fun of in his short stories (2000, 146-147). Eduardo Torres would easily fit in the parochial category, and Monterroso's criticism is directed more against literary practices than against the character itself, as it can be appreciated in the archetypes and topics of Lo demás es silencio - a book we will talk about some lines below—or in the "Note on the Translation." In the former, Monterroso scorns the academic essay, analyzes a Golden Age poem, and plays with the aphoristic genre, for example. In the latter, he points the finger at the need of international sponsorship as a condition for doing archival research or at the dubious mixtures of authors to create the illusion of authority, such as the combination of "Horace and Juvenal among the ancient, Swift and La Bruyère in the modern times, and Orwell and Huxley in our days" $(1965,41)$. In short, Eduardo Torres is a necessary shadow for Monterroso, the ironist.

The "Note on the Translation" has another mystery to solve: the sources of the quotes on translation, which Monterroso did not develop literally elsewhere. However, the Selectathe second section of Lo demás es silencio, among book reviews, lectures, and some other pieces of Torres's intellectual production - includes the essay "Traductores y traidores" (Translators and traitors). This text has been briefly referred to by critics who have centered their attention on the novel. Robert Parsons indicates that it is "an essay written by the apparently monolingual Torres on the subtleties and potential pitfalls of translation" (1989, 940). Noguerol Jiménez summarizes it (2000, 191-192), and Ruffinelli says that it "is based on the absurdity of offering two translations (one, literal; spiritual, the other) of a poem made up by small lines and not by words" (2001, 46; my translation; see fig. 1). 
Figure 1. Source text

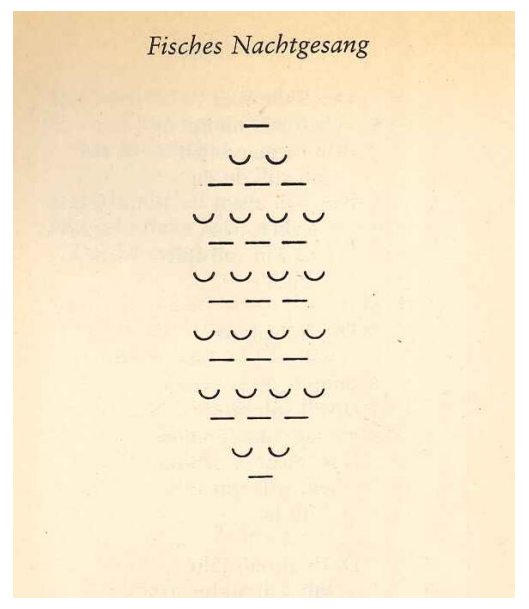

Some additional comments on the Torres/Monterroso's 'translation approach' are worth making, though. Torres's short essay is an ironical reflection on the translational adagio and topoi. It opens with an epigraph: "Flor que toco se deshoja" (The flowers I touch / Lose petals and whiter; Jules Renard's translation [Bécquer 1908, 59]), the second verse of "Mi vida es un erial" (My life is a desert [ibid.]), the gloomy rhyme LX by Gustavo Adolfo Bécquer ([1871] $1891,65)$ that, in the new context, refers to the problem of the untranslatability of poetry. The essay then mocks at the translator-traitor binary to conclude that since all treason must be conscious, all translating treason must be deliberate, ideally, and in consequence (Monterroso [1982] 2001, 127) meaning that translators should be constantly aware of the multiple constraints and possibilities languages offer to render a particular reading of a work.

By using "critical misconstructions in supercilious phrasing" (Noguerol Jiménez 2000, 188; my translation), Torres then ponders the dilemma of translating 'the letter' or 'the spirit,' an opposition that reminds us of Friedrich Schleiermacher's $(2000,229)$ and Eugene Nida's $(1964,162,245)$ idea of the 'spirit of the original message' or, more recently, Berman's renewal of the concept of la lettre $(2014,84)$. After citing Cervantes, Aristotle, Horace, and Epicurus as his authorities, Monterroso offers not an absurdity, as Ruffinelli thinks $(2001,46)$, but a literal and a spiritual translation of a poem by Christian Morgenstern (1871-1914), leaving the good (and the bad) reader free to decide which version is preferable (see fig. 2). Torres/Monterroso's source text (fig. 1) epitomizes the creative experimentation that led to renovating, long-lasting movements, such as the Avant-Garde. The 1905 poem is included in the humorous compositions by the German parodist and satirist, and it has been studied and praised by literary 
critics and referred to by translation professionals and theorists. From the first group, literary critic Michael Cantor clarifies: ${ }^{9}$

The poem consists of alternating lines of macrons and breves, the marks of scansion in Latin and Greek poetry, reimagined as both the shimmering scales of a sleeping fish and musical notations. ... The scansion marks split the poem into one of sound and one of shape....

The macrons and breves cluster in a vaguely fish-shaped form.... The breves look like fish scales of a child's drawing and the macrons might be crude renderings of horizontal fins.

Jed Rasula and Steve McCaffery have rendered the poem's title as "Night Song of the Fish" since "Morgenstern called this night song a phonetic poem" $(1998,8)$, whereas, in his classical treatise The Art of Translation, theorist Jiřy Levý $(2011,126)$ refers to two other translations of the title of the poem to illustrate that "expressivity and factuality are one of the two fundamental requirements in the composition of the title." Levý further explains:

Not only the semantic content of the image but also the stylistic colour and the potential associations should be preserved [when translating titles]. For instance, ... [t] he lyrical irony of Christian Morgenstern's poem Fisches Nachtgesang is better captured in Ludvík Kundera's title Rybi nokturno [A Fish's Nocturno] than in Jindřich Hořejśís generic Nocni zpevryby [The Fish's Night Song]. . . (126; first two brackets added)

Monterroso could not have possibly read Cantor's details on the elaboration of the poem, nor Rasula and McCaffery's study on imaginary languages, or Levý's criticism. However, his choice of Fisches Nachtgesang (A fish's nocturne) suggests that he intended to show how translation may encompass the graphic contrasts of the macrons and breves against the blank page as well as the written word. His versions of the graphic hint at two possible emotional responses, one capable to 'reproduce' the original, the other more creative and 'personal.' Aware of the importance of titles in translation, Torres/Monterroso offers two hues that guide the possible interpretation of the graphic variants (see fig. 2): "La serenata del pez" (A fish's serenade) and "Nocturno en la pecera" (Nocturn in a fishbowl). Despite 'serenade' and 'nocturn' are both good alternatives because they describe musical pieces performed at night, every choice would lead to different associations. On the one hand, 'pez' (fish) refers to one live fish, implying he is free to do the song, inviting the reader to imagine it traversing the

\footnotetext{
${ }^{9}$ Michael Cantor, "Poem Appreciation \#1 - 'Fisches Nachtgesang' (Christian Morgenstern)," Eratosphere (forum), October 21, 2012, http://www.ablemuse.com/erato/showthread.php?t=19015.
} 
water steadily. On the other hand, 'pecera' (fishbowl) would suggest various fish singing in a fishbowl, disturbing each other, and causing the water to tremble.

Figure 2. Translations by Eduardo Torres

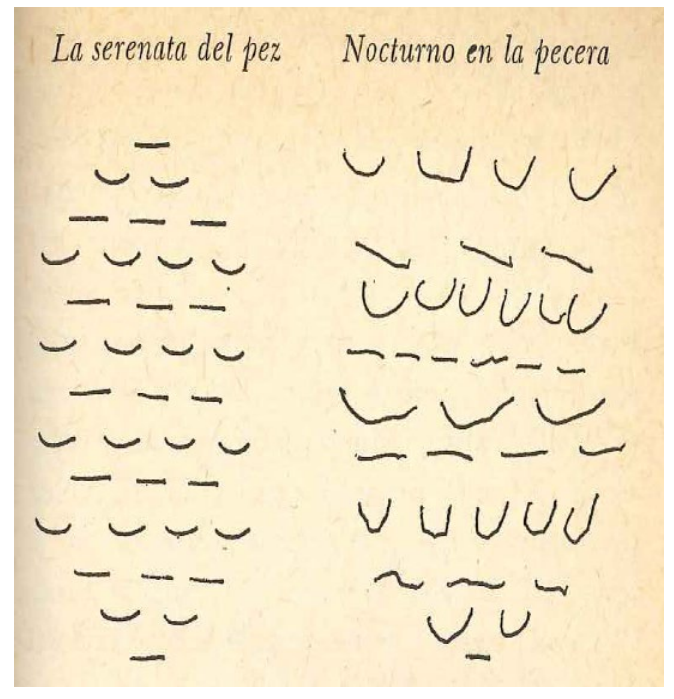

Torres/Monterroso's provision of two headings underlines the guiding purpose of titling. His gesture can be interpreted as the application of the more abstract and critical ideas he posits in his essay "Sobre la traducción de algunos títulos" (On the translation of some titles) - a series of reflections and examples bounded by the idea of the translator's ethical duty of consulting the dictionary when dealing with titles, a blatancy that supports the irony of the piece. "On the translation of some titles" is written deductively under the premise that "la experiencia humana no es acumulativa" (human experience is not of a cumulative nature; Monterroso 1983b, 90; my translation) to justify the treatment of the long-standing issue of translation 'errors.' First, Monterroso mocks subtly at ambitious translation projects, such as Unamuno's determination to let "las leyes que dirigen el comportamiento humano, según Schopenhauer" (the laws that govern human behavior, according to Schopenhauer; Monterroso 1983b, 90; my translation) be known. Then, he insists on the authority and the invulnerability of the literary masterpiece as source text over any translation, to finally admit that all translation is valid only if the reader is not capable to read the work in its original language. At that point, Monterroso demeans ironically the topics of unattainable translation aims and the reverence toward the original text in order to highlight the importance of titles. He begins by discussing the erroneous rendition of four English titles into Spanish which have become fossilized. The 
translation mistakes and their shocking ulterior use by writers and the public are due to the lack of curiosity that prevents translators from looking up at their dictionaries, Monterroso argues (1983b, 202). In short, he aims his criticism at an intellectual flaw which becomes an ethical concern in the translation field and with significant consequences on literary works and language at large.

\section{De te fabula narratur ${ }^{10}$}

Monterroso’s ludic pieces have been praised by Isaac Asimov, Gabriel García Márquez, and Carlos Fuentes (Ruffinelli 2001, 18), among others. As most short fiction and ironic texts do, his work demands a high intellectual activity to uncover the strong critical standing that underlies his irony. His writing demands a constant dialogue with the reader who is presented with riddles, puns, and mirrors that, in the case of Torres's translation and essay, produce a complex array of characters, translators, critics, and authors. In relation to his construction of Eduardo Torres, it is necessary to look into the first quotation in the "Note on the Translation": the cryptic phrase in Latin De te fabula narratur (The legend applies to you), which summarizes superbly the aim of the satire, to understand the constellation of critical-literary voices we have mentioned so far: Swift, Morgenstern, Torres, and Monterroso himself in "On the translation of some titles." The question then would be at whom (or what) Torres/Monterroso is directing his criticism. Saúl Sosnowsky $(1995,37)$ explains that injustice and destruction were strong motivations for Monterroso to write. The criticism then would be directed at writers, critics, and translators alike. The task then would be to reflect on how and when they become accomplices or mere spectators and on the possible ways their writings and translations could voice the injustice. Despite constantly suggested, this idea does not appear explicitly in Monterroso's texts because they are not pamphlets. For instance, the coup d'état in Guatemala is not even hinted at in "Mr. Taylor," bullying is masked as literary criticism in "Epitafio encontrado en el Cementerio Monte Parnaso de San Blas, S. B." ${ }^{11}$ (An epitaph found in Saint Blas, S. B., Mount Parnassus Cemetery), and a lack of ethics in translation supports the irony in "On the translation of some titles."

\footnotetext{
10 "Quid rides? Mutato nomine, de te fabula narratur" (Horacio 1961, 3; What are you laughing at? Names changed, the legend applies to you; my translation).

${ }^{11}$ In La letra E (1984) included in Monterroso 1996, 255.
} 
A similar split between activism and artistic subtlety is found in the construction of Torres. Monterroso never admitted Eduardo Torres was a heteronym, nor a fictional character (Noguerol Jiménez 2000, 173), a gesture that allowed him to place the best of his translating experience in the realm of the literary and leave the pain and trouble he went through as a translator to be treated in his autobiographical testimonies. It is perhaps the following anecdote Monterroso had in mind when he decided that Eduardo Torres would embody the finest and funniest translator ever - a translator and an intellectual who would never suffer injustice and hunger. While in Chile in 1954, Monterroso was offered a translation job for the Ellery Queen magazine, published by the Zig-Zag house, but he quit after six days of struggling with a story by an author who

quería que las cosas marcharan rápido, sin preocuparse para nada por otro estilo que no fuera directamente al espíritu de sus lectores, si es que alguna vez había supuesto que estos lo tuvieran, o por lo menos a su emoción o interés para que al final, sintiéndose buenos, se identificaran con los buenos. [Fue entonces que Monterroso] resuelto a [morir] de hambre antes que a seguir traduciendo aquello, [se presentó] a devolverle para siempre su revista [a la secretaria de Zig-Zag que se la había entregado para luego salir] a la calle bajo el sol deslumbrante y [encaminarse] al río Mapocho, que pasa por ahí, y ... en la orilla y [1lorar] de humillación hasta que, siendo benditamente otra vez las doce, [se incorporó] y [fue] a la venta de vino más cercana y una copa de vino tras otra [lo] volvieron a la vida y a la idea de que todo estaba bien, de lo más bien. (Monterroso 2001, 88)

(wanted things to move along quickly without worrying about options of style that would indirectly reach the soul of his readers, and if he had ever thought they had souls, or that he had touched their emotions or sparked their interests so that in the end, feeling they were good, they would identify themselves with other good people. [It was then that Monterroso] vowed to die of hunger before going on with the translation, [and proceeded] to return forever the magazine to [the Zig-Zag secretary who had previously given it to him, and he went out] to the street under the dazzling sun and [he headed to] the Mapocho River, which ran by there, and . . . he sat down on its bank and [cried] in humiliation until, blessedly, it was twelve noon, and [he got up] and [went] to the nearest wine shop and, one glass of wine after another [took him] came back to life, to the idea that everything was okay, and, just peachy; my translation)

\section{The Joys of Translation}

This same anecdote takes us back to the playfulness implicit both in the construction of Torres and in the choice of the text by Swift in order to explain Monterroso's purpose when translating freely, when he rendered "An Autobiographical Sketch," by Charles Lamb, ${ }^{12}$ and

\footnotetext{
${ }^{12}$ The text was dated "18th April, 1827." It appeared posthumously in The New Monthly Magazine (Lamb 1835).
} 
three of John Aubrey's biographies. ${ }^{13}$ Monterroso (1983a, 38) opens his version of Lamb's text with an epigraph by Eduardo Torres: "Las buenas autobiografías son siempre las biografías ideales de los buenos lectores" (Good autobiographies are always the ideal biographies for good readers; my translation). In a gesture to bring his readers culturally close to Lamb, Monterroso $(1983 a, 39)$ reminds that Cervantes wrote self-portraits, the last one being "apenas cuatro días antes de morir" (just four days before he passed away; my translation). The phrase tends a bridge for the reader to understand the pun in the explanation that Lamb "escribió en una sola página su autobiografía, que es al mismo tiempo su autorretrato, que es al mismo tiempo su despedida y su epitafio, y una hazaña literaria probablemente irrepetible" (1983a, 40; wrote his autobiography in one single page, an autobiography which is both his self-portrait and his farewell and epitaph at the same time, a literary exploit that might never be imitated; my translation). Among the usual biodata, Monterroso (1983a, 39), in a subtle way, justifies his choice of Lamb: "el autor de los Ensayos de Elia, a través de los cuales dejó un testimonio de cómo, pase lo que pase, después de todo, el mundo puede ser visto con una sonrisa" (the author of the Essays of Elia, which were the means by which he conveyed his statement that, despite everything, the world may be observed with a smile; my translation) — a phrase that may well apply to Monterroso's writing.

A similar coincidence can be deduced from his translation of three of Aubrey's 'lives': "William Shakespeare” (1983c), "Desiderius Erasmus" ([1998] 1999, 35-37), and "Thomas More" ([1998] 1999, 39-41). One can infer what Monterroso's beliefs were from what he ([1998] 1999, 11) explains in his prologue to The Cow, from the underlying values of the source text, and from the ways the source text is related to his literary oeuvre. So, we could explain his translation project in terms of friendship, reading, and creativity. 'Friendship' reveals Monterroso's belief in bonding, conversation and sharing; 'reading' tells about his thirst for knowledge, conventional and alternative; 'creativity' would then be the blurring of boundaries between research, writing, and translation so that they become interacting components of his artistic system.

\footnotetext{
${ }^{13}$ Monterroso also translated John Michael Cohen's Poetry of This Age (1963) as Poesía de nuestro tiempo and Ved Mehta's Fly and the Fly-Bottle (1976) as La mosca y el frasco, both for the Mexican government funded publishing house Fondo de Cultura Económica. His probable translation project and the publication details exceed the aims of this paper.
} 
Friendship is the basis of both Monterroso's translation and his source text. Noguerol Jiménez $(2000,192$, n. 102) underlines that in his prologue to The Cow, "señala con humildad que lo único que merece la pena del texto son sus traducciones al español de las biografías de Desiderio Erasmo y Tomás Moro por John Aubrey" (he states humbly that the only valuable moments in the book are his translations into Spanish of Erasmus's and More's biographies by John Aubrey; my translation), and we may add that Monterroso's ([1998] 1999, 11) only expectation is that his friends would thank him for his renditions. Aubrey's Brief Lives is also a tribute to the friendship he had with John Milton, Thomas Hobbes, and Robert Boyle, for example. The Late English Renaissance chronicler and antiquary originally intended Brief Lives to be a collection of "materials on poets" (Aubrey 2018, 1268) that developed into a series of lives of Oxford University. There he met Anthony Wood, his patron and friend, in 1667. Aubrey contributed "his exceptional social gifts" (xlix), Wood his seriousness and discipline, ${ }^{14}$ and both their skills, resources, and interests ${ }^{15}$ to the composition of a collection of varied biographies. Kate Bennett indicates that Brief Lives expresses the idea

that communities may be sustained, increased, and fortified under stress, in exile, or over time through the telling of 'diverting' stories about their members; and that these stories are traditions which preserve historical information that no other form of record could. (Aubrey 2018, xlv)

Even though we may never know how Monterroso came across Brief Lives, his early translation ${ }^{16}$ of three biographies presents him as the acute reader of a rather complex work in terms of content, composition, and context. Monterroso's source text was Oliver Lawson Dick's edition of Aubrey's Brief Lives, first published in 1949. A contemporary critic has observed that “[Dick] added extracts from Aubrey's many other manuscript collections . . . and cut out anything he considered unimportant, especially Aubrey's hesitations and changes of mind.... The result is a flamboyant, streamlined version of Aubrey's intricate paper museum" (Aubrey 2016). However, Dick's editorial procedures were not only correct but crucial for a deeper

\footnotetext{
${ }^{14}$ An example of his work is Athenae Oxonienses (1691-1692), "the first serious attempt at an English biographical dictionary" (Aubrey 2018, lxxi).

15 "[Aubrey and Wood] had much in common. Both were Royalists who had been in Oxford during the civil war, and were to write accounts of that time; both were horrified at the destruction of ancient memorials; and both had responded to their destruction by transcribing and sketching buildings, coats of arms in college windows, old inscriptions, and the like" (Aubrey 2018, xcvii; see also xcvi-xcvii).

${ }^{16}$ Actually, Brief Lives has only been partially retranslated twice into Spanish: by Natalia Babarovic and Miriam Heard (Santiago de Chile: Ediciones Universidad Diego Portales, 2010) and by Fernando Toda Iglesia (Sevilla: La Uña Rota, 2017).
} 
appreciation of Aubrey's life, context, and legacy. Dick underlined Aubrey's skills as a writer able to "[address] not to the mind alone, but to the imagination, and the unerring skill with which he chose just that episode in a man's life when his personality was most extravagantly in bloom [gave] even the shortest of his biographies a vividness which has never been excelled" (Aubrey 1949, cix). Although Monterroso did not have access to Bennett's thorough study of Aubrey's Brief Lives, as we do now, Dick's exhaustive and touching biography of Aubrey-as well as his recognition that he "had the rare gift of creating, and not just recording, life" (cxiii) should have allowed Monterroso to appreciate some of the salient features of Aubrey's book. Monterroso might have sensed the various areas involved in the making of each biography, for example. Bennett explains that this feature is probably due to the influence of Bacon's The Advancement of Learning, which "represents the mind as a house of knowledge furnished with facts. In Aubrey's terminology, supellex means, as Bacon wittily translated it, 'stuff': provisions, equipment, furniture, stock, and importantly, movable property" (Aubrey 2018, xciv).

Monterroso might have also sensed Aubrey's early restoring to oral testimonies, manuscripts, and realia which contemporary historians now include among their legitimate sources. He should have felt attracted to the tension between the 'facts' told about Shakespeare and the dubiousness created by phrases like "I guesse," "at one of the Play-houses," "I thinke I have been told that," and "I have heard" (Aubrey 2018, 275-276). ${ }^{17}$ We may even speculate that they could have influenced his way to construct the testimonies around Eduardo Torres in Lo demás es silencio. Furthermore, Monterroso might have enjoyed imagining Erasmus, the

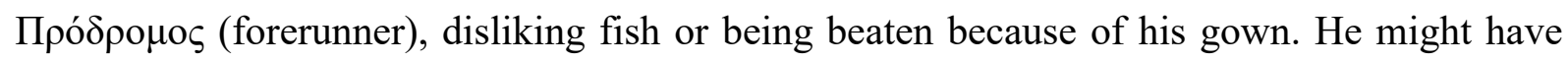
been surprised to learn the causes of his poverty or that there once existed a portrait of him as well. Instead of broadening his knowledge of More's political and philosophical achievements, Monterroso might have laughed at the anecdote of the madman, and he had been more than amused at envisioning the very improbable transit between a utopic situation and its true-life occurrence within More's own household. ${ }^{18}$

\footnotetext{
${ }^{17}$ In contrast, Bennett updates the approach to Aubrey's work by doing research to correct imprecise information, provide data on the people mentioned in the biography, speculate on which were Aubrey's sources, and compare his version to other Shakespeare's biographies (see Aubrey 2018, vol. II, 1267-1276).

${ }^{18}$ Such an absurdity was triggered by gossiping. Aubrey indicates that he heard it from a Mrs. Tyndale, and Bennett explains that "Dorothy Tyndale ... . [was] wife of Thomas Tyndale. The Tyndales were John Aubrey's near neighbours and the source of the raciest gossip in the Lives" (Aubrey 2018, vol. II, 1179). Bennett insists on the fact that although Aubrey "intended to preserve Brief Lives in the discreet shades of a library, it circulated among
} 
Besides the amusement Brief Lives afforded him, Monterroso should have intuited a couple of subtleties between his own writing and Aubrey's: their withdrawal from 'facts' and their unorthodox composition technique. As we tried to explain a few lines above, Monterroso avoided being a mere teller and restored to imagination and satire to envision a wittier world. In Aubrey's case, having experienced war and its aftermath, "the gentlemanly mediator sometimes heard and saw what he wanted to hear and see: a less brutal world" (Aubrey 2018, 1xiii). Lo demás es silencio and Brief Lives are both based on testimonies, documents of all sorts, inscriptions, and realia. They reflect writing as a fine means to revitalize memory and imagination in the end. For both of them, writing could be the final and legitimate repository of an all-encompassing sensibility towards the joy of conversation or the beauty kept in manuscripts or in objects themselves. Writing becomes then the site where fiction and fact espouse the authenticity and the dubiousness in the narratives of the lives of Eduardo Torres or of William Shakespeare, of Thomas More alike. Some critics "took [Aubrey] not as a historian but a mere gossipmonger, a second-rank collaborator, and an undisciplined collector" (Aubrey 2018, xlvii) Still, they fail to appreciate Aubrey's careful gathering of information for preservation purposes. Another critic limited his appreciation of Eduardo Torres to a mere "burla regocijante, fina y despiadada . . . Nada que no sea de risa" (Bonifaz 1979, x; nothing but a joyful, fine, and merciless joke; my translation). However, it is Monterroso's deep control over the rhetoric of all literary genres and their criticism that allows him to create a convincing character in sharp novel that even trespasses the limits of life and fiction.

\section{Closing Comments}

The fictional relationship between Monterroso and Torres renews the Golden Age Spanish parody in which an erudite scholar preserves the work of a fictional poet, as it was the case of Lope de Vega and Tomé de Burguillos, which, in turn, satirizes Fernando de Herrera's critical treatment of Garcilaso's poetry or José de Pellicer's commentaries on Góngora's (De Vega 2008, 19), for example. The Torres/Monterroso persona goes further by presenting a fictional author-translator who established a reputation of his own, to the point that it is still:

\footnotetext{
his trusted friends. However, by May 1683 he was beginning to be worried about this, and told Wood that 'I thinke it not at all prudent in me, to consent that ever' the Lives manuscripts 'should goe out of your hands whilest you live: and I ought to castigate, and castrate some things too true, and biting"” (2018, lxiv-lxv).
} 
difícil ... predecir qué fortuna haya de tener Eduardo Torres en el futuro de la literatura hispanoamericana, más allá de afirmar que al presente vive y permanece en México con completos derechos de ciudadanía, y que es citado, referido, alabado y vilipendiado, ya a menudo visto al sesgo con suspicacias y celos. (Ruffinelli 2001, 48)

(difficult ... to predict the fortunes and misfortunes [he] might have in the future or Hispano-American literature [for] he lives and remains in Mexico benefiting from his citizenship rights, and he is quoted, cited, praised, and blamed, and he is often glanced at with dubiousness and jealousy; my translation)

Ruffinelli's semi-ironic appraisal helps differentiate Eduardo Torres from those translator characters in contemporary literature "whose fragmented identities are a reflection of a fragmented modern world, in which displacement is a widespread phenomenon," as Sabine Strümper-Krobb (2003, 117) observes. The Torres/Monterroso personae chronotrope differentiates from more recent experiments in that the satirical genre provides them with a steady basis to develop, not only in their plots, but in the translation practices and questions they explore. Satirical devices such as parodies, inversions, distortions, and hyperboles normally silence information (names, places, situations) to function properly. The procedures to identify and fill those blanks contribute to the unity of the Torres/Monterroso personae and cohere the ideas on translation that he posits in various occasions. Even the 'incongruities' found in Torres's translation of Swift reveal Monterroso's plan to add credibility to both Torres and the version that the character produces; that is, a translation is the clear result of the background and experiences revealed in the novel Lo demás es silencio.

The target text-found in a dubious archive-, the lost sources of the quotations from Torres, a biography composed by the scraps of memory of those who were acquainted with him, and the written documentation on and by him gathered from factual and fictional sources alike not only reinforce the depiction of Torres as a specular masquerade of Monterroso, his creator, but also mask Monterroso, the author, the man, and the translator he was. As Juan Goytisolo in The Garden of Secrets or Maryse Condé in Crossing the Mangrove would do years after Monterroso, the Torres/Monterroso plasticity establishes an organic, changing relationship with the Other in linguistic, cultural, and self-identity terms, close to the point of fragmentation.

The Torres/Monterroso personae ridiculed hackneyed translation topics, such as the traitor metaphor, while their satirical grounding anticipated a wider idea of translation, one that would include critical reflection on its processes and even the option to transfer graphic elements and not only words — a possibility we would accept nowadays. In other terms, beyond 
the initial smile, the Torres/Monterroso personae advocated, as Clive Scott puts it, a "mode of translation which ... capture[d] reading as a phenomenological, rather than as an interpretative, activity" $(2013,1)$.

Both the minute details of Torres's translation and essay, as well as their larger satirical frame, are consistent with what Monterroso labelled as 'protean':

Lo que parece proteico, lo es; pero como lo es todo organismo vivo. Y yo pretendo que mi novela sea un organismo vivo, que se mueva, que se pueda ver en conjunto como un paisaje, y, de otro modo, hasta con un microscopio para observar moverse sus incontables partes, porque cada frase y cada palabra y cada coma tienen una intención y están allí por algo. (Moreno-Durán quoted in Noguerol Jiménez 2000, 169)

(What seems to be protean [in a human body] is protean; protean as all living organisms. And I intend my novel to be a living, moving organism. I want it to be seen as a whole, like a landscape. I also want it to be observed through a microscope, so that one can observe its minute parts moving, because every phrase and every word and every comma do have an intention and a reason to be there; my translation)

His notion of the 'protean' also applies to the translations of Aubrey and of Lamb he did to please his friends, as he declared. A literary approximation to his two source texts under the light of his larger creative production makes speculation possible on his translation project. His preference for Swift is an implicit declaration of his political beliefs and of the subtlety irony opens. His choosing of three of Aubrey's biographies is consistent with his interest in the making of a character as convincingly as possible because lives, after all, are composites of various orders that can be (re)arranged according to changing motivations. Such a composition may include the blurring of life and death by literary means, as it is implicitly declared in Monterroso's translation of Lamb's humorous and witty "Autobiography." Monterroso's election of Aubrey might also respond to extraliterary reasons, such as the will to create an alternative, gladder world either by artistic means, as Monterroso proposed, or by scientific procedures, as Aubrey intended. In Monterroso, translation is triggered by a literary parody and literature is triggered by translation, translation criticism, and translation studies. The chain trespasses the limits of fictional universes and material, extra-para-literary lives. By translating, and by impersonating a translator, Monterroso rounded up his poetic aims. 


\section{References}

Aubrey, John. 1949. Aubrey's Brief Lives. Edited by Oliver Lawson Dick from the original manuscripts. London: Secker and Warburg.

_. 2016. Aubrey's Brief Lives. With an introduction by Ruth Scurr. N.p.: Vintage Digital. https://www.penguin.com.au/books/aubreys-brief-lives-9781473521735.

- 2018. Brief Lives with an Apparatus for the Lives of Our English Mathematical Writers. Edited by Kate Bennett. 2 vols. New York: Oxford University Press.

Bécquer, Gustavo Adolfo. (1871) 1891. Rimas [Rhymes]. San Francisco: History Company. https://archive.org/details/rimas01bcgoog/page/n1/mode/2up.

- 1908. The "Rimas" of Gustavo A. Bécquer. Translated by Jules Renard. Boston: Gorham Press. https://archive.org/details/rimasgustavoabe00renagoog/page/n72/mode/2up.

Berman, Antoine. (1995) 2009. Toward a Translation Criticism: John Donne. Translated and edited by Françoise Massardier-Kenney. Kent: The Kent State University Press.

- 2014. La traducción de la letra o el albergue de lo lejano [Translation of the letter or the auberge of the foreign]. Translated by Ignacio Rodríguez. Buenos Aires: Dedalus.

Bonifaz Nuño, Alberto. 1979. "Te hablo, Monterroso, para que me escuches, Eduardo Torres (Lo demás es silencio)." [I address you, Monterroso, so that you, Eduardo Torres, may listen to me (The rest is silence).] La Cultura en México, no. 887, ix-x.

De Vega, Lope. 2008. Rimas humanas y divinas del licenciado Tomé de Burguillos [Rhymes, human and divine, by the licentiate Tomé de Burguillos]. Edited by Macarena Cuiñas Gómez. Madrid: Cátedra.

Hewson, Lance. 2011. An Approach to Translation Criticism: Emma and Madame Bovary in Translation. Amsterdam: John Benjamins.

Horacio. 1961. Sátiras [Satires]. Translated by Francisco Montes de Oca. México: UNAM.

Jack, Jane H. 1980. "The Periodical Essayists." In The Pelican Guide to English Literature, edited by Boris Ford, 4:217-229. New York: Penguin.

Lamb, Charles. 1835. “An Autobiographical Sketch.” The New Monthly Magazine and Literary Journal 43:499-501.

Levý, Jiří. 2011. The Art of Translation. Translated by Patrick Corness. Edited by Zuzana Jettmarová. Amsterdam: John Benjamins.

Monterroso, Augusto. (1978) 2001. Lo demás es silencio: La vida y la obra de Eduardo Torres [The rest is silence: The life and work of Eduardo Torres]. México: Cátedra. 
—, trans. 1983a. "La autobiografía de Charles Lamb." [The autobiography of Charles Lamb.] In La palabra mágica [The magic word], 38-42. México: ERA.

1983b. "Sobre la traducción de algunos títulos." [On the translation of some titles.] In La palabra mágica [The magic word], 88-96. México: ERA.

— magic word], 102-105. México: ERA.

. 1996. Tríptico: Movimiento perpetuo; La palabra mágica; La letra E [Triptych: Perpetual movement, the magic word, the letter e]. México: Fondo de Cultura Económica.

\section{—_. (1998) 1999. La vaca [The cow]. México: Alfaguara.}

— 2001. "Crying on the Banks of the Mapocho River." Translated by Zoë Anglesey. Special Issue on Latin America, Bomb, no. 74, 86-88. https://www.jstor.org/stable/40426557. Originally published as "Llorar orillas del río Mapocho" in La palabra mágica [The magic word], 15-16 (México: ERA, 1983).

Nida, Eugene. 1964. Toward a Science of Translating. Leiden: E. J. Brill.

Noguerol Jiménez, Francisca. 2000. La trampa en la sonrisa: Sátira en la narrativa de Augusto Monterroso [The trap in the smile: Satire in Augusto Monterroso's prose]. Sevilla: Universidad de Sevilla.

Parsons, Robert A. 1989. "Parody and Self-Parody in Lo demás es silencio: (La vida y la obra de Eduardo Torres) by Augusto Monterroso." Hispania 72 (4): 938-945. doi:10.2307/343572.

Phiddian, Robert. 1996. "Have You Eaten Yet? The Reader in A Modest Proposal." Studies in English Literature, 1500-1900 36 (3): 603-621. http://www.jstor.org/stable/450801.

Rasula, Jed, and Steve McCaffery, eds. 1998. Imagining Language: An Anthology. Cambridge: MIT Press.

Ruffinelli, Jorge. 1989. "La audacia cautelosa." [The cautious audacity.] In Viaje al centro de la fábula [A journey to the center of the fable], by Augusto Monterroso, 17-31. México: Era.

- 2001. Introduction to Lo demás es silencio: La vida y la obra de Eduardo Torres [The rest is silence: The life and work of Eduardo Torres], by Augusto Monterroso, 7-54. México: Cátedra.

Schleiermacher, Friedrich. 2000. Sobre los diferentes métodos de traducir [On the different methods of translating]. Translated by Valentín García Yebra. Madrid: Gredos. 
Scott, Clive. 2013. Literary Translation and the Rediscovery of Reading. Cambridge: Cambridge University Press.

Sosnowski, Saúl. 1995. "Monterroso: la sátira del poder." [Monterroso: A satire on power.] Chap. 4 in Refracción: Augusto Monterroso ante la crítica [Refractions: Augusto Monterroso before criticism], edited by Wilfrido H. Corral. México: UNAM.

Strümper-Krobb, Sabine. 2003. "The Translator in Fiction." Language and Intercultural Communication 3 (2): 115-121. doi:10.1080/14708470308668095.

Swift, Jonathan. (1729) 1996. "A Modest Proposal: For Preventing the Children of Poor People in Ireland, from Being a Burden on Their Parents or Country, and for Making Them Beneficial to the Publick." In A Modest Proposal and Other Satirical Works, 52-59. New York: Dover.

Torres, Eduardo, trans. 1965. "Modesta proposición." [Modest proposal.] With a note on the translation by Augusto Monterroso. Revista de Bellas Artes, no. 6, 41-51.

Walker, Hugh. 1915. The English Essay and Essayists. New York: E. P. Dutton. 